\title{
Bioclimatic diagnosis for poultry in municipalities of Mato Grosso, Brazil
}

DOI: $10.53499 /$ sfjeasv1n2-002

Received in: February 1st, 2021

Accepted in: March 31th, 2021

\author{
Pedro Hurtado de Mendoza Borges \\ $\mathrm{PhD}$ in Agricultural Machinery from the University of Rostock, Germany \\ Institution: Mato Grosso University Federal University \\ Address: Av. Fernando Corrêa da Costa nº 2367, Boa Esperança, Cuiabá - MT, Brazil \\ E-mail: pedrohmborges14@gmail.com \\ Zaíra Morais dos Santos Hurtado de Mendoza \\ $\mathrm{PhD}$ in Forest Science from the Federal University of Viçosa \\ Institution: Mato Grosso University Federal University \\ Address: Av. Fernando Corrêa da Costa nº 2367, Boa Esperança, Cuiabá - MT, Brazil \\ E-mail: zairamorais09@gmail.com \\ Pedro Hurtado de Mendoza Morais \\ Agronomy undergraduate student at the Federal University of Mato Grosso \\ Institution: Mato Grosso University Federal University \\ Address: Av. Fernando Corrêa da Costa nº 2367, Boa Esperança, Cuiabá - MT, Brazil \\ E-mail: pedromorais08@hotmail.com
}

\section{Charles Esteffan Cavalcante}

Agronomy undergraduate student at the Federal University of Mato Grosso Institution: Mato Grosso University Federal University

Address: Av. Fernando Corrêa da Costa nº 2367, Boa Esperança, Cuiabá - MT, Brazil

E-mail: charlescavalcante05@gmail.com

\begin{abstract}
This study aimed to determine the enthalpy index in three municipalities of Mato Grosso, to characterize the bioclimatic profile for the poultry industry. In the research, the compensated daily dry bulb temperature and the daily average relative humidity were used. The data corresponding to a historical series of 35 years, between 01/01/1985 and 12/31/2020, recorded in conventional meteorological stations in the municipalities of Canarana, Nova Xavantina, and Santo Antônio de Leverger, available in the Meteorological Database for Teaching and Research of the National Institute of Meteorology (INMET). Then, monthly descriptive statistics of the historical series were determined and bar plot graphs with enthalpy values were developed. These graphs included the lower and upper enthalpy limits, suitable for laying hens and broilers, to qualify the thermal conditions of environmental comfort in the three municipalities of Mato Grosso. It was concluded that the enthalpy index made it possible to characterize the bioclimatic profile of the mentioned municipalities for poultry farming, according to the months of the year. The natural thermal conditions in these municipalities were not favorable to poultry farming, requiring extra investments in the air conditioning of the sheds. The increase in thermal discomfort for broilers was accentuated from the fourth week of the production cycle. The applied methodology presented itself as an adequate tool to assist in the elaboration of projects related to environmental changes in aviaries.
\end{abstract}

Keywords: Animal welfare, ambience in rural facilities, thermal comfort. 


\section{INTRODUCTION}

Brazil is a world reference in the poultry sector, with expressive exports and a high domestic consumption due mainly to the new eating habits of the population and more accessible prices when compared to other sources of protein. Nationally, the Midwest region occupies the third position in broiler and laying poultry, with Mato Grosso being the second largest exporter of eggs in 2019 and the first in this region (ABPA, 2020). In addition, the state leads the production of corn and soybeans in the country, which are important sources of raw material used in concentrated feed for poultry (CONAB, 2020).

When it comes to the growth and modernization of Brazilian agribusiness, Mato Grosso is increasingly consecrated as a national leader and the development of poultry farming is part of this escalation within the state, which has been presenting an entrepreneurial capacity for poultry projects. Rodrigues et al. (2014) emphasized that the search for new breeders in the poultry industry would be an interesting action of the agribusiness in different regions of the country because it could promote and encourage the construction of new facilities and the development of integration agreements, generating a profitable long-term investment option. However, sustainability requires the adoption of viable technologies that aim to increase productivity and/or reduce costs concomitant with practices that ensure production health, animal welfare, and minimal impact on the environment.

In recent years, the increase in temperatures, resulting from global warming, has caused considerable losses to producers, who have been requiring investments for the air conditioning of poultry houses (AMARAL et al., 2016). According to these authors, the option of acclimatized houses in the country may favor the growth of production in warmer Brazilian regions, such as the Midwest. According to Barbosa Filho (2004), Mendes and Paz (2008), Nascimento et al. (2011), Santos et al. (2014a, b), the thermal environment of the house has a direct influence on the productive and reproductive performance of the birds. In this sense, temperature, relative humidity, and wind speed constitute the tripod of thermal comfort in poultry houses. Therefore, knowledge of these climatic variables is relevant to support the design of the facilities and define elements such as orientation, materials, and ventilation system.

Among other criteria, the thermal conditions in poultry facilities have been evaluated based on the enthalpy index (MACARI and FURLAN 2001, BARBOSA FILHO et al. 2007 and 2009, NAZARENO et al. 2009, GARCIA et al. 2015, AKAMINE and PASSINI 2017, BENINCASA et al. 2017, QUEIROZ et al. 2017, FERRAZ et al. 2018, ROMANO et al. 2018, SILVA et al. 2018, HARADA et al. 2021. Thus, this study is based on the hypothesis that the cited index can qualify the thermal environment to assist in the construction of poultry facilities. The addressed theme motivated the present 
research, which aimed to determine the enthalpy index in municipalities of Mato Grosso, aiming to characterize the bioclimatic profile for poultry farming.

\section{MATERIAL AND METHODS}

The research used the daily values of average compensated daily temperature and average daily relative humidity, available in the Meteorological Database for Teaching and Research (BDMEP) of the National Institute of Meteorology (INMET), in the period from January 1985 to December 2020. The selection of the municipalities was based on the following criteria: having a meteorological station operating for 30 years or more, having altitude different by $150 \mathrm{~m}$ or more, and being located near important access roads, such as federal or state highways. Thus, the municipalities of Mato Grosso Canarana, Nova Xavantina, and Santo Antônio de Leverger were chosen (Figure 1). The continuous cartographic bases of the Brazilian Institute of Geography and Statistics (IBGE) and the QGIS program (IBGE, 2021; QGIS, 2020) were used to elaborate this figure.

The conventional weather station in Canarana is located at coordinates $-13.47^{\circ}$ latitude and $52.27^{\circ}$ longitude with an altitude of $430 \mathrm{~m}$, has code OMM 83270, and has been operating since 04/08/1987. In Nova Xavantina, this class of station was installed at coordinates $-14.70^{\circ}$ latitude and $52.35^{\circ}$ longitude with an altitude of $316 \mathrm{~m}$, has code OMM 83319, operating since 08/05/1987. In the municipality of Santo Antônio de Leverger, there is the Padre Ricardo Remitter conventional weather station at the coordinate's latitude $-15.7833^{\circ}$ and longitude $-56.0667^{\circ}$ with an altitude of $140 \mathrm{~m}$, code OMM 83364, operating since 01/01/1986. The climate of this tropical region has been classified as Aw (PEEL et al., 2007; ALVARES et al., 2013), ranging the average annual temperature from $15.9^{\circ} \mathrm{C}$ to $35.1^{\circ} \mathrm{C}$ and oscillating the average annual rainfall between $1210 \mathrm{~mm}$ and $1735 \mathrm{~mm}$ (INMET, 2021). 


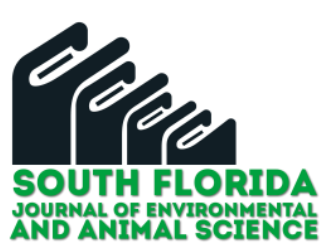

Figure 1. Location of the selected municipalities in the state of Mato Grosso, Brazil.

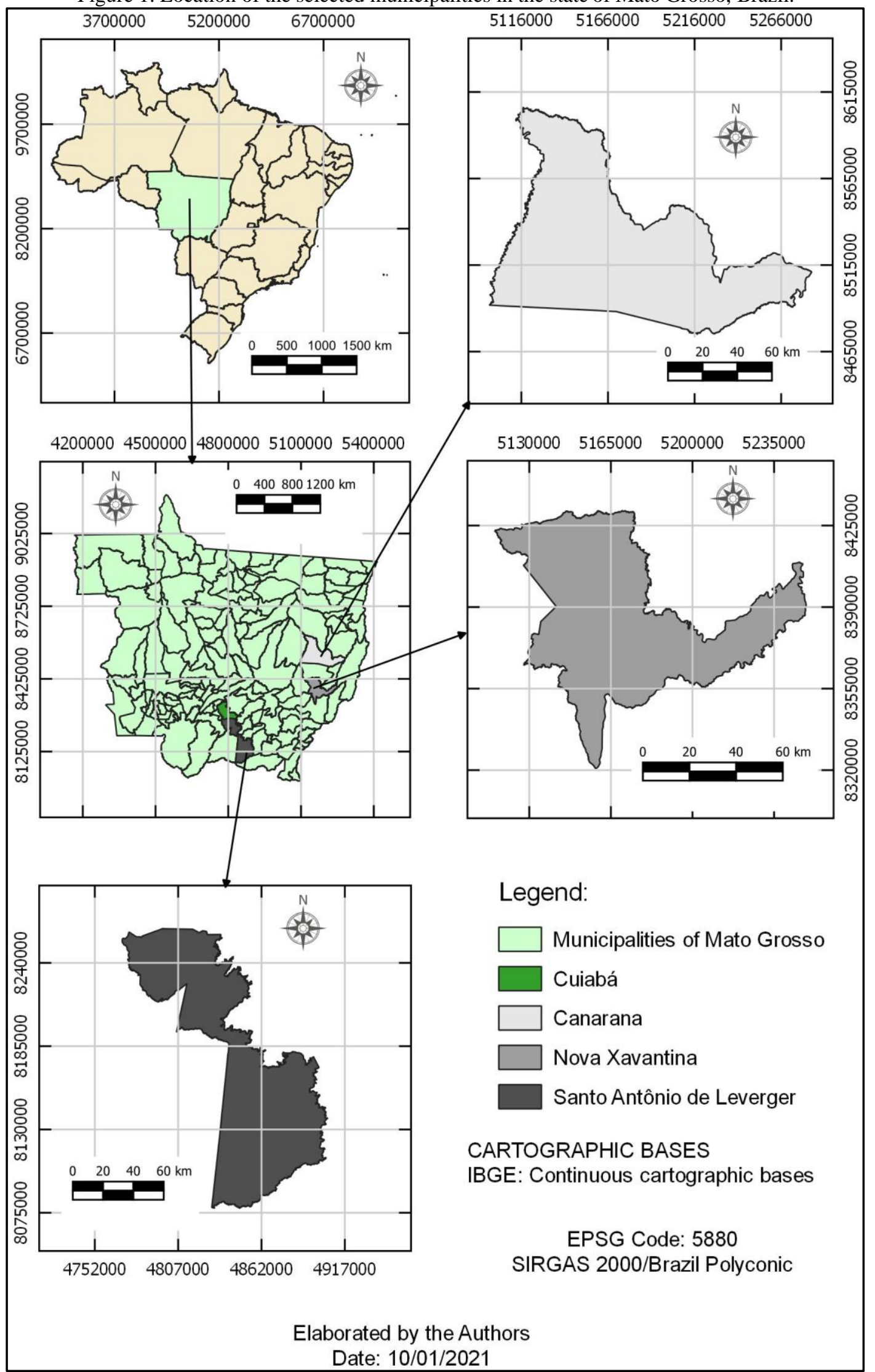


The values of the variables temperature and relative humidity, obtained from the Meteorological Database for Teaching and Research of the National Institute of Meteorology, were stored in EXCEL spreadsheets. Then, the filter and classification tools of this spreadsheet were used to detect and eliminate probable flaws that occurred during the filling of the records. Thus, it was possible to select valid data to estimate the enthalpy index $(\mathrm{H})$, according to the empirical expression proposed by Barbosa Filho (2007), given by the following equation:

$$
\mathrm{H}=\left[6,7+0,243 \cdot \mathrm{T}_{b 5}+\right.
$$

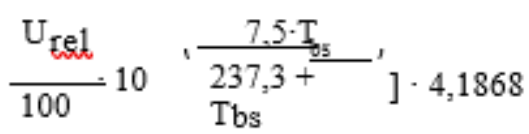

Where: $\quad \mathrm{H}=$ Enthalpy Index $(\mathrm{kJ} \cdot \mathrm{kg}-1$ of dry air);

Tbs $=$ Air or dry bulb temperature $\left({ }^{\circ} \mathrm{C}\right)$;

Urel $=$ Relative humidity $(\%)$.

Based on the literature, the ideal enthalpy index intervals were verified, according to the characteristics of the birds, adapted from studies by Macari and Furlan, 2001; Barbosa Filho et al., 2007 and Harada et al., 2021 (Tables 1 and 2). Next, the proceduresfor data analysis were performed with the aid of the R Program (R CORE TEAM, 2020).Thus, the main descriptive statistics of the meteorological variables were determined, based on the measures of position and dispersion for the three municipalities. Subsequently, the column graphs with the monthly mean values of the enthalpy index were prepared, indicating the appropriate enthalpy limits. For layers, the limits corresponded to the criteria of comfort, alert, danger, and emergency. In the case of broilers, the limits were defined according to the production cycle.

Table 1. Ranges for classifying the thermal condition of layers, according to enthalpy limits.

\begin{tabular}{cccc}
\hline Interval & \multicolumn{2}{c}{ Limits } & Thermal condition \\
& Lower & Superior & Comfort \\
2 & 56,1 & 64,6 & Alert \\
3 & 64,7 & 70,5 & Review \\
4 & 70,6 & 77,5 & Lethal \\
\hline
\end{tabular}

Source: Adapted by the authors from Macari and Furlan (2001) and Harada et al. (2021).

Table 2. Limit values of the enthalpy index to characterize the thermal condition of poultry.

\begin{tabular}{cccccc}
\hline \multirow{2}{*}{ Week } & Limits & \multicolumn{4}{c}{ Thermal condition } \\
\cline { 3 - 5 } & & Comfort & Alert & Danger & Emergency \\
\hline \multirow{2}{*}{ First } & Lower & 77,0 & 88,6 & 106,6 & 122,4 \\
& Superior & 83,3 & 106,5 & 122,0 & 145,8 \\
\multirow{2}{*}{ Second } & Lower & 66,9 & 77,3 & 93,3 & 106,5
\end{tabular}




\begin{tabular}{|c|c|c|c|c|c|}
\hline & Superior & 77,0 & 92,8 & 106,4 & 127,6 \\
\hline \multirow[t]{2}{*}{ Third } & Lower & 57,7 & 67,2 & 80,7 & 92,7 \\
\hline & Superior & 66,9 & 80,6 & 92,5 & 121,9 \\
\hline \multirow[t]{2}{*}{ Fourth } & Lower & 49,5 & 57,8 & 69,8 & 80,2 \\
\hline & Superior & 57,7 & 69,6 & 80,1 & 116,4 \\
\hline \multirow[t]{2}{*}{ Farm } & Lower & 39,6 & 55,1 & 66,3 & 76,7 \\
\hline & Superior & 54,9 & 66,2 & 76,3 & 111,1 \\
\hline \multirow[t]{2}{*}{ Sixth } & Lower & 37,4 & 52,2 & 63,1 & 72,7 \\
\hline & Superior & 52,1 & 63,0 & 72,6 & 106,0 \\
\hline
\end{tabular}

Source: Adapted by the authors from Barbosa Filho et al. (2007).

\section{RESULTS AND DISCUSSION}

Table 3 shows the main descriptive statistics of the monthly dry-bulb temperature for the three municipalities of Mato Grosso. The lowest average temperatures were observed during June and July for the three municipalities. According to the values of standard deviation and coefficient of variation, the average compensated room temperature showed high variability in the historical series because these measures of dispersion were higher than $3.03^{\circ} \mathrm{C}$ and $11.35 \%$, respectively.

Table 3 Mean compensated dry bulb temperature values $\left({ }^{\circ} \mathrm{C}\right)$, standard deviation $\left({ }^{\circ} \mathrm{C}\right)$, and coefficient of variation $(\%)$ in the year for the three municipalities in the state of Mato Grosso, Brazil.

\begin{tabular}{llll}
\hline $\begin{array}{l}\text { Month of the } \\
\text { year }\end{array}$ & Canarana & Nova Xavantina & Santo Antônio de Leverger \\
\hline January & $25,06 \pm 4^{, 95}(19,74)$ & $25,64 \pm 5^{, 22}(20,35)$ & $26,97 \pm 4^{, 44}(16,45)$ \\
February & $24,96 \pm 4^{, 21}(16,88)$ & $25,63 \pm 4^{, 96}(19,36)$ & $26,78 \pm 4^{, 77}(17,80)$ \\
March & $25,21 \pm 4^{, 37}(17,32)$ & $25,68 \pm 4^{, 20}(16,38)$ & $26,83 \pm 5^{, 33}(19,88)$ \\
April & $25,33 \pm 3^{, 80}(14,99)$ & $25,46 \pm 4^{, 95}(19,46)$ & $26,36 \pm 5^{, 19}(19,67)$ \\
May & $24,70 \pm 3^{, 17}(12,81)$ & $24,00 \pm 3^{, 47}(14,45)$ & $24,15 \pm 3^{, 85}(15,94)$ \\
June & $24,06 \pm 4^{, 34}(18,03)$ & $22,55 \pm 3^{, 86}(17,13)$ & $23,02 \pm 3^{, 97}(17,25)$ \\
July & $24,14 \pm 3^{, 80}(15,76)$ & $22,11 \pm 3^{, 38}(15,29)$ & $22,36 \pm 4^{, 47}(19,99)$ \\
August & $26,05 \pm 3^{, 73}(14,31)$ & $24,32 \pm 4^{, 33}(17,79)$ & $24,78 \pm 5^{, 34}(21,56)$ \\
September & $27,35 \pm 3^{, 64}(13,33)$ & $26,71 \pm 5^{, 01}(18,77)$ & $26,93 \pm 4^{, 72}(17,52)$ \\
October & $26,71 \pm 3^{, 03}(11,35)$ & $27,23 \pm 4^{, 10}(15,05)$ & $27,88 \pm 3^{, 45}(12,39)$ \\
November & $25,76 \pm 3^{, 05}(11,84)$ & $26,24 \pm 4^{, 63}(17,64)$ & $27,50 \pm 5^{, 14}(18,68)$ \\
December & $25,12 \pm 3^{, 27}(13,01)$ & $25,80 \pm 4^{, 76}(18,44)$ & $27,25 \pm 4^{, 70}(17,26)$ \\
\hline
\end{tabular}

Exponents preceded by \pm represent the standard deviation $\left({ }^{\circ} \mathrm{C}\right)$ and values in parentheses correspond to the coefficient of variation $(\%)$.

During nine months of the year, in the cities of Canarana and Nova Xavantina, the average compensated temperature values were below the ideal range for layers recommended by Barbosa Filho (2007), which should vary between $26^{\circ} \mathrm{C}$ and $34^{\circ} \mathrm{C}$. For the municipality of Santo Antônio de Leverger, the situation was different, with eight months of the year with temperatures within the suggested range. However, feed consumption changes by about $1.72 \%$ for each $1{ }^{\circ} \mathrm{C}$ oscillation in environmental temperature between $18^{\circ} \mathrm{C}$ and $32^{\circ} \mathrm{C}$ (PLAVNIK, 2003). Also, according to this author, the change of $1^{\circ} \mathrm{C}$ for temperatures between $32^{\circ} \mathrm{C}$ and $38^{\circ} \mathrm{C}$ can cause a reduction in feed consumption close to $5 \%$, which 
influences egg size and weight (BERTECHINI, 2012).

Regardless of the municipality and month of the year, the average compensated temperature values were below the ideal limits for poultry during the first two weeks of the production cycle, which should range between $29^{\circ} \mathrm{C}$ and $35^{\circ} \mathrm{C}$ (ABREU and ABREU, 2002; SILVA, 2007; SILVA et al., 2008). However, the municipality of Santo Antônio de Leverger showed a more favorable condition, because the differences concerning the minimum value of the mentioned interval were small for eight months of the year.

The main descriptive statistics of the average relative humidity are shown in Table 4. The municipalities of Canarana and Nova Xavantina showed a similar humidity condition, with the lowest values being observed in the period between May and November. However, the municipality of Santo Antônio de Leverger had the lowest humidity values between June and December. The values of the dispersion measures were high for all months and municipalities, indicating great variability throughout the historical series.

Table 4: Values of mean relative humidity (\%), standard deviation (\%) and coefficient of variation (\%) inthe year for the three municipalities in the state of Mato Grosso, Brazil.

\begin{tabular}{llll}
\hline $\begin{array}{l}\text { Month of the } \\
\text { year }\end{array}$ & Canarana & Nova Xavantina & Santo Antônio de Leverger \\
\hline January & $85,77 \pm 22^{, 47}(26,20)$ & $87,11 \pm 12^{, 49}(14,34)$ & $81,96 \pm 13^{, 48}(15,74)$ \\
February & $86,23 \pm 20^{, 01}(23,20)$ & $87,24 \pm 14^{, 57}(16,70)$ & $83,25 \pm 14^{, 825}(15,26)$ \\
March & $86,12 \pm 18^{, 86}(21,89)$ & $87,24 \pm 15^{, 39}(17,65)$ & $83,11 \pm 13^{, 30}(22,49)$ \\
April & $81,93 \pm 18^{, 56}(22,66)$ & $84,43 \pm 24^{, 29}(28,77)$ & $82,14 \pm 15^{, 02}(14,60)$ \\
May & $72,62 \pm 10^{, 57}(14,55)$ & $79,22 \pm 13^{, 59}(17,15)$ & $80,90 \pm 14^{, 05}(27,36)$ \\
June & $63,13 \pm 18^{, 20}(28,83)$ & $75,75 \pm 17^{, 96}(23,71)$ & $77,53 \pm 11^{, 25}(27,18)$ \\
July & $53,05 \pm 12^{, 61}(23,77)$ & $68,40 \pm 18^{, 06}(26,41)$ & $70,56 \pm 9^{, 68}(15,88)$ \\
August & $45,99 \pm 7^{, 23}(15,72)$ & $61,22 \pm 11^{, 31}(18,47)$ & $61,74 \pm 12^{, 22}(17,38)$ \\
September & $53,48 \pm 12^{, 90}(24,12)$ & $61,77 \pm 8^{, 71}(14,11)$ & $61,36 \pm 9^{, 42}(23,90)$ \\
October & $71,74 \pm 18^{, 17}(25,32)$ & $73,83 \pm 17^{, 18}(23,27)$ & $68,89 \pm 9^{, 12}(28,54)$ \\
November & $80,74 \pm 21^{, 79}(26,98)$ & $83,26 \pm 12^{, 02}(14,44)$ & $75,14 \pm 13^{, 01}(16,30)$ \\
December & $85,12 \pm 14^{, 78}(17,37)$ & $86,73 \pm 13^{, 86}(15,98)$ & $79,39 \pm 16^{, 64}(25,68)$ \\
\hline
\end{tabular}

Exponents preceded by \pm represent the standard deviation $\left({ }^{\circ} \mathrm{C}\right)$ and values in parentheses correspond to the coefficient of variation $(\%)$.

In the municipality of Canarana, the relative humidity was satisfactory for June, within the ideal range for layers, as proposed by Barbosa Filho (2007), which is between 63\% and 67\%. For the municipalities of Nova Xavantina and Santo Antônio de Leverger, this condition of relative humidity was favorable during August and September. The municipality of Canarana had eight months with humidity above the ideal range and three below, while in the municipalities of Nova Xavantina and Santo Antônio de Leverger the relative humidity, for ten months, was above the maximum limit of the recommended range. 
Regarding poultry, the municipality of Canarana presented the lowest number of months with relative humidity ranging between $60 \%$ and $80 \%$, ideal limits suggested by Abreu and Abreu (2002); Silva (2007); Silva et al. (2008). On the other hand, the municipalities of Nova Xavantina and Santo Antônio de Leverger reached this condition in six and seven months, respectively. It is also noteworthy that the highest values of relative humidity corresponding to the municipality of Santo Antônio de Leverger were close to the upper limit cited, which favors the poultry industry.

Figure 2 shows the average monthly enthalpy values for the municipalities of Canarana, Nova Xavantina, and Santo Antônio de Levenger, as well as the limits of the intervals to classify the thermal condition of the layers. In this Figure, it is verified that the thermal environment in the three municipalities varied between the comfortable limits for layers, only during July. The alert situation is verified for May, June, August, and September. However, for the remaining seven months a dangerous enthalpy was reached. The results obtained indicate that the natural environment of the evaluated municipalities was not adequate for egg-laying aviculture, that is, the projects of aviaries require special attention, about the covering and climatization, which can lead to extra costs and high investments.

Figure 2. Distribution of mean monthly enthalpy values in the evaluated municipalities and ideal limits forcharacterizing the thermal environment of layers during the production cycle.

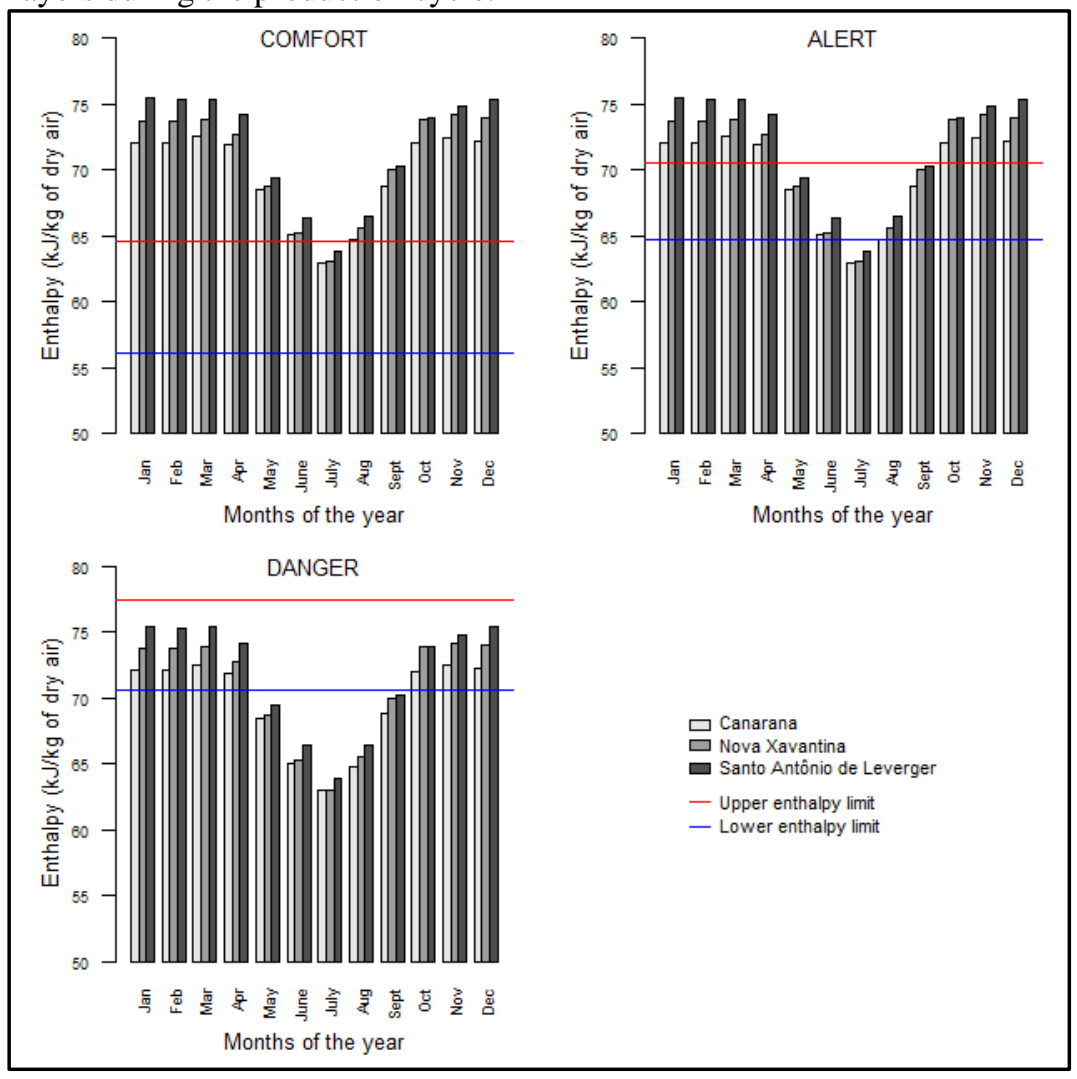


In the three municipalities of Mato Grosso, the average monthly enthalpy values were not suitable for the first week of the production cycle of poultry during the months of May, June, July, August and September (Figure 3). In the remaining months, a favorable condition was observed only in Nova Xavantina and Santo Antônio de Leverger. Regarding the second week of the production cycle, the situation was not appropriate in the three cities, only during the months of June, July and August. However, these months were favorable for the third week of the cycle. In general, enthalpy values below the comfort range indicate cold stress in the birds, worsening the situation in the first week, when their thermoregulation mechanisms are not fully adapted.

Figure 3. Distribution of mean monthly enthalpy values in the evaluated municipalities and ideal limits tocharacterize the thermal environment for poultry in the first three weeks of the production cycle.

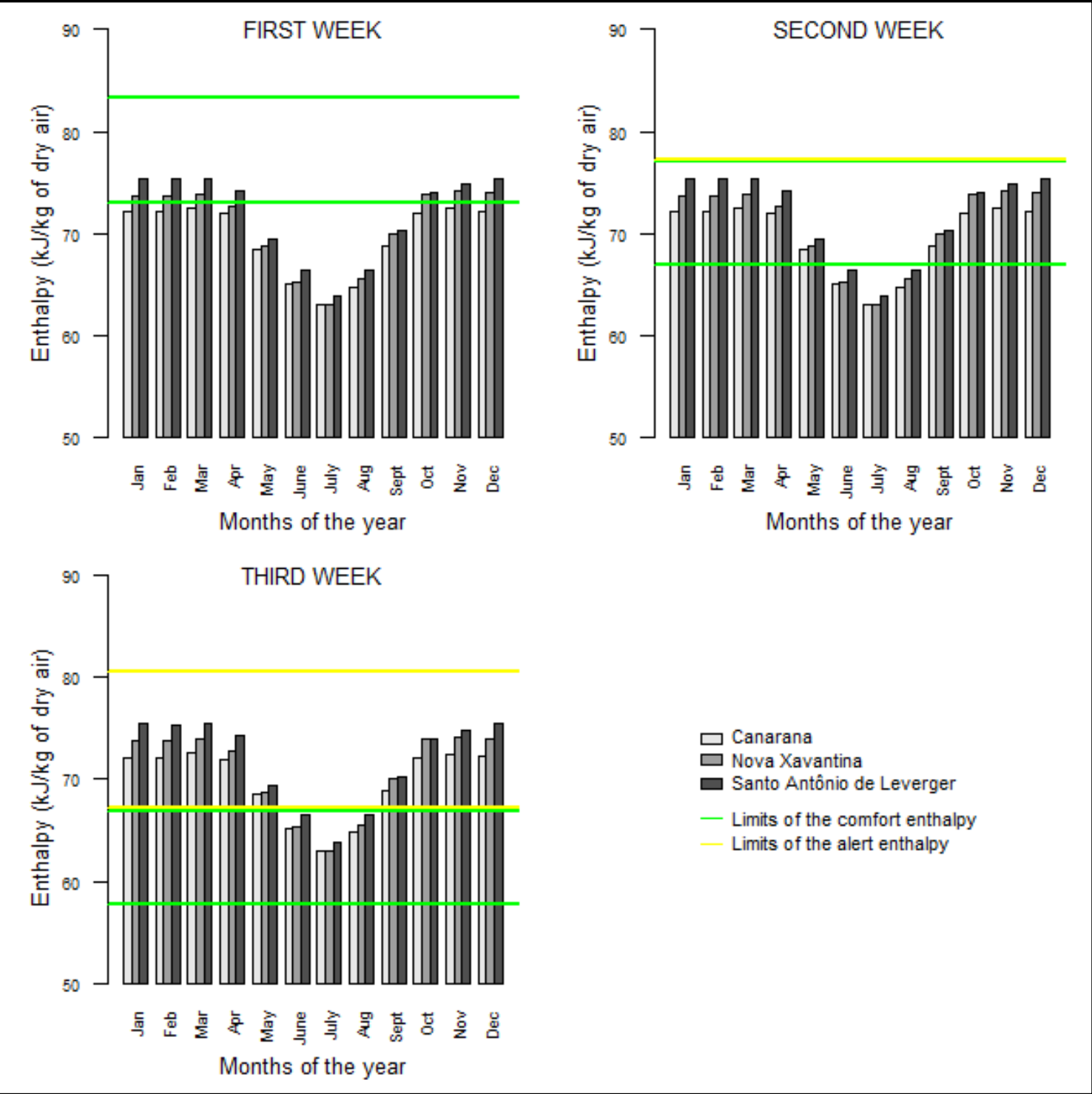




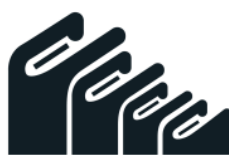

Figure 4. Distribution of mean monthly enthalpy values in the evaluated municipalities and ideal limits tocharacterize the thermal environment for poultry in the last three weeks of the production cycle.

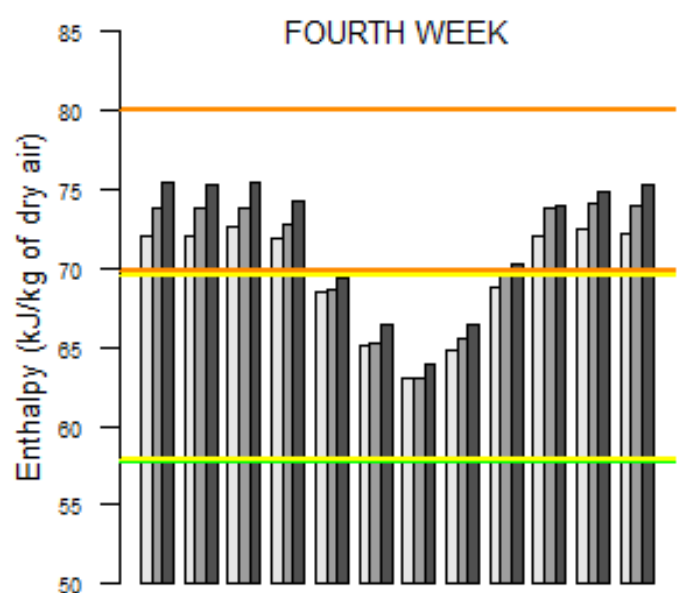

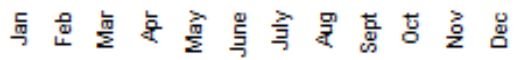

Months of the year

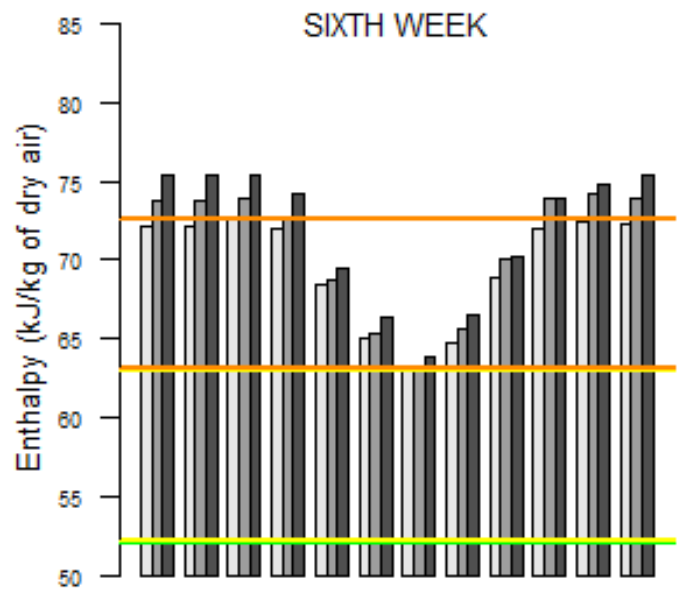

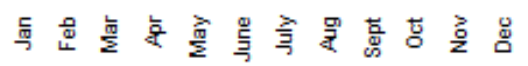

Months of the year

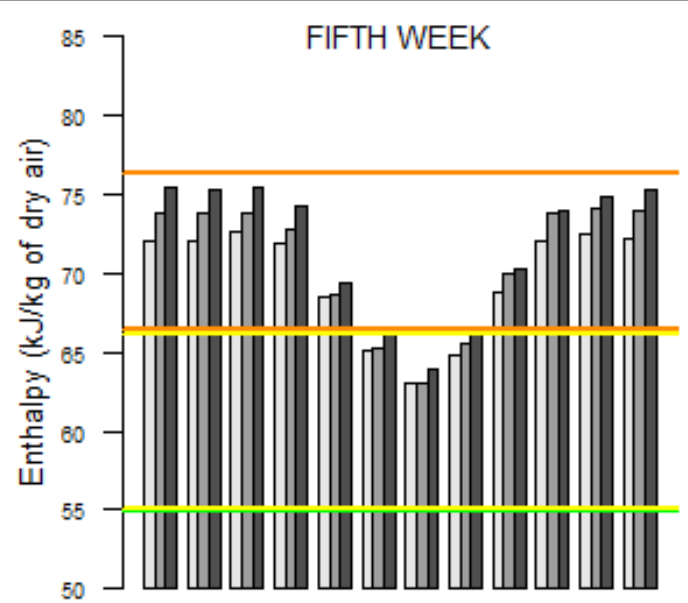

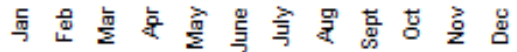
Months of the year

It should be emphasized that the last three weeks correspond to the most critical period of the production cycle of broilers, in which the poultry producer has already hadseveral expenses with day-old chicks, inputs, feed, water, energy, among others, and thuscould have irreversible losses caused by heat stress. The enthalpy values estimated for theselected locations in this research demonstrated the need to alleviate thermal discomfort through environmental modifications in poultry houses, with emphasis on the design of the roof and the ventilation system. According to Akamine and Passini (2017), recycled tiles (tetrapak) on the roof can reduce enthalpy by up to $12.8 \%$. In addition, the enthalpydifference throughout the day can vary between 3.9 and $7.5 \mathrm{~kJ} \cdot \mathrm{kg}-1$ of dry air (QUEIROZet al., 2017). Based on these studies, it is inferred that the proper design for the cover of the facilities in the three selected municipalities can satisfy the thermal comfort conditionsof the birds during most of the year. 


\section{CONCLUSION}

The enthalpy index made it possible to characterize the bioclimatic profile of the municipalities in Mato Grosso selected for poultry production, according to the months of the year. The natural thermal conditions in these municipalities were not favorable forpoultry production, requiring extra investments in the acclimatization of the houses. Theincrease in thermal discomfort for poultry became more pronounced after the fourth weekof the production cycle. The methodology applied presented itself as an adequate tool toassist in the elaboration of projects related to environmental changes in poultry houses.

\section{ACKNOWLEDGMENTS}

To the National Institute of Meteorology (INMET) for allowing the consultation of data from conventional weather stations in the municipalities of Canarana, Nova Xavantina and Santo Antônio de Leverger, Mato Grosso, Brazil. To the Brazilian Instituteof Geography and Statistics (IBGE) for allowing access to the continuous cartographic bases. 


\section{REFERENCES}

ABPA - BRAZILIAN ASSOCIATION OF ANIMAL PROTEIN. Annual Report 2020.

Poultry meat and eggs. São Paulo: Annual Report Publications, 2020.

ABREU, V. M. N.; ABREU, P. G. Diagnóstico bioclimático para o Estado do Paraná.Concórdia: Embrapa Suínos e Aves (Technical Communication 320), 2002.

AKAMINE, L. A.; PASSINI, R. Thermal comfort indices for poultry in reduced models with different coverings. Revista ESPACIOS, Panama, v.38, n.6, p.7, 2017. Available at: https://www.revistaespacios.com/a17v38n06/17380607.html

ALVARES, C. A.; STAPE, J. L.; SENTELHAS, P. C.; GONÇALVES, J. L. M.; SPAROVEK, G. Köppen's climate classification map for Brazil. MeteorologischeZeitschrift, Stuttgart, v.22, n.6, p.711-728, 2013.

DOI: http://dx.doi.org/10.1127/0941-2948/2013/0507

AMARAL, G.; GUIMARÃES, D.; NASCIMENTO, J. C.; CUSTODIO, S. Avicultura de postura: estrutura da cadeia produtiva, panorama of the sector in Brazil and theworld and the BNDES' support. Rio de Janeiro: BNDES Sector 43, p. 167-207, 2016.

BARBOSA FILHO, J. A. D. Avaliação do bem-estar de aves poedeiras em diferentessistemas de produção e condições ambientais, utilizando análise de imagens. Dissertation (master's in animal science) - University of São Paulo (USP), Piracicaba, 2004.

BARBOSA FILHO, J. A. D.; VIEIRA, F.M.C.; GARCIA, D.B.; SILVA, M.A.N.;

SILVA, I.J.O. Mudanças e uso das Tabelas de Entalpia. Piracicaba, São Paulo, 2007.Available at: http://www.nupea.esalq.usp.br/pagina/frangos-de-corte/11

BARBOSA FILHO, J. A. D.; VIEIRA, F. M. C.; SILVA, I. J. O.; GARCIA, D. B.; SILVA, M. A. N.; FONSECA, B. H. F. Transport of chickens: characterization of the microclimate in the load during the winter. Revista Brasileira de Zootecnia, Viçosa, v.38, n.12, p.2442-2446, 2009.

BENINCASA, N. C.; SAKAMOTO, K. S.; SILVA, I. J. O. Post-showroom ambience: climatic characterization of transport and waiting in industrial poultry farming and severity of scratches originating during the pre-slaughter phase. In: VII Brazilian Congress on Biometeorology, Ambience, Behavior and Animal Welfare, 2017. Jaboticabal, SP. Annals... 2017, p.1-5.

DOI: https://doi.org/10.6084/m9.figshare.5176900

BERTECHINI, A. G. Nutrição de monogástricos. 2 edn. EdUFLA: Federal University of Lavras, Lavras. 2012.

CONAB - NATIONAL SUPPLY COMPANY. Boletim de Monitoramento Agrícola (Agricultural Monitoring Bulletin). Brazilian crop of grains. Brasília: Companhia Nacional de Abastecimento. 2020. Available at: https://www.conab.gov.br/info-agro/safras/graos 
FERRAZ, P. F. P.; FERRAZ, G. A. S.; PEREIRA, R. S. G.; CASTRO, J. O.; CADAVID, V. G. Enthalpy distribution in chicken house in the first week of life. In: XXVIII BRAZILIAN CONGRESS OF ZOOTECHNY, 2018. Goiânia, GO. Proceedings... 2018, Paper 0040.

Available at: http://www.adaltech.com.br/anais/zootecnia2018/listaresumos.htm

GARCIA, E. R. de M.; NUNES, K. C.; CRUZ, F. K.; FERRAZ, A. L. J.; BATISTA, N.

R.; BARBOSA FILHO, J. A. Behaviour of layers reared at different housing population densities. Arquivos de Ciências Veterinárias e Zoologia da UNIPAR, Umuarama, v. 18, n. 2, p. 87-93, abr./jun. 2015.

Available at: https://revistas.unipar.br/index.php/veterinaria/article/view/5378/3078

HARADA, E. S.; MONTANHANIOS, M. E. S.; BUENO, L. G. F.; NETO, M. M.;

SOUZA, S. R. L.; FONSECA, R. Enthalpy-based decision trees for comfort assessment for light layers in a tropical climate. Research, Society and Development, Vargem Grande Paulista, v.10, n.3, p.1-9, 2021.

DOI: http://dx.doi.org/10.33448/rsd-v10i3.13354

IBGE - BRAZILIAN INSTITUTE OF GEOGRAPHY AND STATISTICS. Bases

Cartográficas Contínuas. Rio de Janeiro: 2021. Available at: https://www.ibge.gov.br/geociencias/cartas-e-mapas/bases-cartograficas-continuas.html

INMET - NATIONAL INSTITUTE OF METEOROLOGY. BDMEP: Meteorological

Database for Teaching and Research. Brasília: 2021.Available at:

https://bdmep.inmet.gov.br/

MACARI, M.; FURLAN, R. L. Ambiência na produção de aves em clima tropical. In: SILVA, I. J. (Ed.) Ambiência na produção de aves em clima tropical. Piracicaba: FUNEP,2001. p. 31-87.

MENDES, A. A.; PAZ, I. C. L. Protocolo de boas práticas para produção de frangos.São Paulo: UNIÃO BRASILEIRA DE AVICULTURA - UBA. 2008.

NASCIMENTO, G. R.; PEREIRA, D. F.; NÄS, I. A.; RODRIGUES, L. H. A. Fuzzy index of thermal comfort for broilers. Engenharia Agrícola, Jaboticabal, v.31, n.2, p.219-229, 2011.

NAZARENO, A. C.; PANDORFI, H.; ALMEIDA, G. L. P.; GIONGO, P. R.; PEDROSA, E. M. R.; GUISELINI, C. Evaluation of thermal comfort and performance of broilers under differentiated rearing regime. Revista Brasileira de Engenharia Agrícola e Ambiental, Campina Grande, v.13, n.6, p.802-808, 2009.

DOI: https://doi.org/10.1590/S1415-43662009000600020

PEEL, M. C.; FINLAYSON, B. L.; MCMAHON, T. A. Updated world of the Köppen- Geiger climate classification. Hydrology and Earth System Sciences, Göttingen, v.11, n.5, p.1633-1644, 2007. DOI: https://doi.org/10.5194/hess-11-1633-2007

PLAVNIK, I. Poultry nutrition in warm climates. APINCO Conference - BrazilianAssociation of Poultry Chick Producers. Campinas. 2003.

QGIS DEVELOPMENT TEAM. QGIS Geographic Information System. Open Source Geospatial Foundation Project. Version 3.12.0-București. 2020. 
QUEIROZ, M. L. V.; BARBOSA FILHO, J. A. D.; SALES, F. A. L.; LIMA, L. R.;

DUARTE, L. M. Spatial variability of the environment in broiler houses with misting system. Revista Ciência Agronômica, Fortaleza, v. 48, n. 4, p. 586-595, oct-dez, 2017. Available at:

https://www.scielo.br/j/rca/a/9p9TyxyY7zvD8zXWLxynM6K/?format=pdf\&lang=pt

R CORE TEAM. R: A language and environment for statistical computing. R Foundation for Statistical Computing, Vienna, Austria. Version 3.5, 2020.

RODRIGUES, W. O. P.; GARCIA, R. G.; NÄÄS, I. A.; ROSA, C. O.; CALDARELLI,

C. E. Evolução da avicultura de corte no Brasil. Enciclopédia Biosfera, Goiânia, v.10,n.18, p.16661684, 2014.

ROMANO, G. G.; MIRANDA, K. O. S.; DEMATTÊ FILHO, L. C.; CARVALHO, L. C. Thermal environment of laying birds kept in the free-range system. In: III Seminar of Rural Constructions and Ambience Applied to Animal Production, 2018. Tupã, SP. Annals... 2018.

SANTOS, G. B.; SOUSA, I. F.; BRITO, C. O.; SANTOS, V. S.; BARBOSA, R. J.;

SOARES, C. Estudo bioclimático das regiões litorânea, agreste e semiárida do estado deSergipe para a avicultura de corte e postura. Ciência Rural, Santa Maria, v.44, n.1, p.123-128, 2014a.

SANTOS, R. C.; BATTILANI, M.; GARCIA, R. G.; GEISENHOFF, L.; JORDAN, R.

A. Comparison between environmental assessment systems in laying hen houses in the region of Dourados - MS. Brazilian Journal of Biosystems Engineering, Tupã, v.8, n.2,p.183-190, 2014b.

SILVA, E.T. Índice de temperatura e umidade (ITU) na produção de aves para a Mesorregião do Nordeste e Norte pioneiro Paranaense. Revista Acadêmica, Curitiba, v.5, n.4, p.385-390, 2007.

SILVA, E.T; LEITE, D. G.; YURI, F. M.; NERY, F. S. G.; REGO, J. C. C.; ZANATTA, R. A.; SANTOS, S. A.; MOURA, V. V. Diagnóstico bioclimático para mesorregião metropolitana de Curitiba - PR. Scientia Agraria, Curitiba, v.9, n.4, p.521-526, 2008. DOI: http://dx.doi.org/10.5380/rsa.v9i4.12513

SILVA, N. C.; SANTOS, R. C.; ZUCCA, R.; CESCA, R. S.; GEISENHOFF, L. O. Use of thermal indices for analysis of broiler production regions in Mato Grosso do Sul. Encyclopedia Biosfera, Goiânia, v.15, n. 28, p. 907-915, 2018.

DOI: http://dx.doi.org/10.18677/EnciBio_2018B74 